\title{
Assessing Health Risk in Livestock through Quantification of Iron in Forages, Soil and Buffalo Blood from Sargodha, Pakistan
}

\author{
YONGJUN YANG1, ZAFAR IQBAL KHAN²*, KAFEEL AHMAD², \\ MUHAMMAD FAHAD ULLAH ${ }^{3}$, MUHAMMAD NADEEM ${ }^{4}$, \\ HUMAYUN BASHIR ${ }^{1,6}$, MUDASRA MUNIR ${ }^{2}$, IFRA SALEEM MALIK ${ }^{2}$, \\ NIMRA ARSHAD ${ }^{2}$, JING MA ${ }^{1}$, FU CHEN ${ }^{1}$, ILKER UGULU ${ }^{5}$ \\ ${ }^{1}$ School of Environment Science and Spatial Informatics, China University of Mining and Technology, Xuzhou, China \\ ${ }^{2}$ Department of Botany, University of Sargodha, Pakistan \\ ${ }^{3}$ Department of Earth Sciences, University of Sargodha, Sargodha, Pakistan \\ ${ }^{4}$ Institute of Food Science and Nutrition, University of Sargodha, Pakistan \\ ${ }^{5}$ Faculty of Education, Usak University, Usak, Turkey \\ ${ }^{6}$ Institute of Molecular Biology and Biotechnology, The University of Lahore, Lahore, Pakistan
}

\begin{abstract}
Air pollution is very important issue now-a-days. This has affected the components of environment to a great extent. Organisms like animals, plants and human beings are forced to live in such polluted environments. One of the pollution sources to the environment is vehicular traffic which has toxic effect on the roadside plants. In this study, roadside forages, soil and buffalo blood were studied to estimate the level of heavy metal pollution, iron in particular, in Sargodha from six chosen sites at perimeter of major roads. Collected samples were processed and digested for quantification of iron by atomic absorption spectrophotometer. Soil and buffalo samples from the site $V$ showed high concentration of iron, whereas in forage, samples collected from site IV had greatest iron concentration. The bio concentration factor found for forage-soil was highest in the samples collected from site IV. On the other hand, bio-concentration factor for blood-forage and pollution load index was found highest in the samples collected from site $V$. Correlation for soil-forage and blood-forage was found negatively non-significant. The daily intake of metals for iron was found highest for site IV. The Health risk index was highest for the samples collected from site VI.
\end{abstract}

Keywords: forage, soil, iron, buffalo blood, bio-concentration factor

\section{Introduction}

Biota has been adversely affected by pollution caused by various agents in the environment. Most concerning factor causing pollution is the heavy traffic on roads. Biota has been adversely affected by pollution caused by various agents in the environment. Most concerning factor causing pollution is the heavy traffic on roads [1]. Rusting of body parts of automobiles, burning of lubricants and fuel, wear and tear of tires, removal of paint, and breakage of the batteries are the major operations of the automobiles from which heavy metals are added to the atmosphere. $\mathrm{Cu}, \mathrm{Fe}, \mathrm{Pb}, \mathrm{Zn}$ and $\mathrm{Cd}$ are added to the environment via these pollution sources [2-4]. Throughout the world the inorganic pollution caused by heavy metals has been a matter of grave concern [5-9]. Intensity of the traffic on roads affects the extent of heavy metal pollution. Low fuel quality and fuel inefficient vehicles intensify the traffic associated pollution [10]. The elevated concentrations of heavy metals released from heavy traffic pose extremely toxic effects on the living organisms like roadside plants [11, 12]. Plant growth along with metabolic processes of plants is widely affected by heavy metal accumulation in soft plant parts [1315]. Stomata openings are blocked by dust and heavy metals inhibiting gaseous exchange.

Heavy metals cause cellular damage, metabolic disorders, inhibit enzyme function, disturb biochemical and physiological processes and stunt shoot/root growth [16] decreasing the productivity of plants [17].

*email: zafar.hed@gmail.com 
Animal feeding areas close to the roads are mainly subjected to heavy metal contamination. This heavy metal toxicity is responsible for appearance of various diseases among animals. In the past and even now various studies have been carried out in order to find the exposure of toxic metals to the animals. Healthy diet is needed by animals so that they could remain safe from the direct hazardous effects of the toxic heavy metals on animal health and indirect effects on the human health [18]. Heavy metals after getting entry into food chain cause various disorders. Heavy metals pose dangerous effects on each and very trophic level of food chain [19]. As these heavy metals step up each trophic level, these become more and more toxic simultaneously. Some of these heavy metals are eliminated by the bodies of organisms but some heavy metals could not be eliminated. So they remain accumulating in the bodies of organism causing severe damage.

The removal of the toxic heavy metals from the bodies of the living organisms is a matter of concern [20]. For the management and monitoring of the heavy metals in the environment the technique named phyto-monitoring is gaining much importance. This technique utilizes a number of wild and cultivated plant species. In order to gain accurate knowledge about the heavy metals' existence in the environment, the selection of plant to be used as a phyto-monitor is quite important [21]. The most important species in this respect are Rosa rugosa [22], Sagittaria sagittifolia [23] and Nerium oleander [24].

The need of hour is that the heavy metals concentration of the road side forages, soil and the blood of animals like buffalo rearing on these forages should be analyzed. To assess the heavy metal pollution caused by roadside traffic this study was carried out. So that the remedies of eliminating heavy metals from the environment could by chalked out which is a very important and concerning issue now-a-days.

\section{Materials and methods}

\subsection{Study area}

Sargodha is an east central city of Punjab. The climate of Sargodha is very hot in summer especially in May, June and July. The summer temperature mostly reaches $50^{\circ} \mathrm{C}$ in aforementioned months. River Chenab flows on the eastern side of the city while river Jhelum flows on the western and northern sides. The surrounding areas of Sargodha contain fertile and irrigated land having a variety of domestic plants and wild species.

Current study was carried out at six sites (major roads) in Sargodha city, five of them were at the road perimeters while one was away from main road. Five roadside sites (I-V) were: Mateela, Faisalabad, 50 Chak and Bhalwal road. Sixth site (VI) was the site away from the road; Dera Saudi. Sampling was done in summer and winter seasons respectively. Winter sampling was done in December and January 2016 and summer sampling was done in May and June 2016.

\subsection{Processing of samples}

After the collection of soil and forage from the six sites of Sargodha, they were subjected to air drying. The collected forages were Trifolium alexandrinum Triticum aestivum, Pennisetum glaucum and Sorghum bicolor. 120 samples of forages and soil were collected in two seasons while the 60 samples of buffalo blood were collected in winter and summer seasons respectively. The buffalo blood serum was separated by centrifugation for further analysis. The soil and forage samples were oven dried at 70$75^{\circ} \mathrm{C}$ for 7 days after their oven drying.

\subsection{Acid digestion and mineral analysis}

Soil samples (1 $\mathrm{g}$ each) were digested according to Kilburn [25] in a digestion flask with 7.5mL HCL and $2.5 \mathrm{~mL} \mathrm{HNO}_{3}$. Forage samples $\left(0.5 \mathrm{~g}\right.$ each) were digested using $1.5 \mathrm{~mL} \mathrm{HCIO}_{4}$ and $5 \mathrm{~mL} \mathrm{HNO}_{3}$ [26]. Blood serum was digested following the protocol devised by Richards [27]. All samples (soil, forage, blood) were obtained as clear solutions and their final volume was made up to $50 \mathrm{~mL}$ by adding distilled water. Mineral analysis was carried out in atomic absorption spectrophotometer (AA 6300 Shimadzu Japan). 


\subsection{Analysis of data using statistical tools}

Analysis of variance and correlation was calculated by using two-way ANOVA. Statistical program for Social Sciences (SPSS) was aiding tool to find the above parameters. The levels of probability were $0.05,0.01$ and $0.001[28]$.

\subsection{Bio-concentration factor}

Bio-concentration factor $(\mathrm{BCF})$ is defined as rate of the total metal concentration in the plant to that in the soil.

$$
B C F=\frac{\text { amount of trace metal in edible part }}{\text { amount of trace metal in soil }}
$$

and similarly for blood plasma

$$
B C F=\frac{\text { metal concentration in blood plasma }}{\text { metal concentration in forage }}
$$

\subsection{Daily intake of metals}

The daily intake of metals (DIM) was given by Chary and his collaborators [29].

$$
D I M=\frac{C_{\text {metal }} \times C_{\text {daily food intake }}}{B_{\text {average weight }}}
$$

In this equation:

$\mathrm{B}_{\text {average weight }}$ - quotes for average body weight of a buffalo of that particular area where the study conducts.

The average daily forage consumption per animal taken as $12.5 \mathrm{Kg}$ and average body weight referred as $550 \mathrm{Kg}$ per cattle

$\mathrm{C}_{\text {metal }}$ - concentrations of metals,

$\mathrm{C}_{\text {daily food intake }}$ - daily consumption of forage per cattle per day in $\mathrm{Kg}$ [30]

\subsection{Health risk index and pollution load index}

Daily intake of metals in food crops divided by the oral reference dose (Table 1) was referred to as Health risk index (HRI)[31].

Table 1. Oral reference dose and reference values of iron in soil

\begin{tabular}{|c|c|c|}
\hline Metal & $\underline{\mathrm{RfD}(\mathrm{mg} / \mathrm{kg} / \text { day) }}$ & $\begin{array}{c}\text { Reference value } \\
(\mu \mathrm{g} \mathrm{g})\end{array}$ \\
\hline $\mathrm{Fe}$ & $0.7^{\mathrm{a}}$ & $56.90^{\mathrm{b}}$ \\
\hline
\end{tabular}

$$
H R I=\frac{D I M}{R_{f} D}
$$

Pollution load index (PLI) was given by Liu and his collaborators [32].

$$
P L I=\frac{C_{\text {Soil }}}{C_{\text {reference values }}}
$$

where; $\mathrm{C}($ reference $)=$ metal concentration taken as reference $($ Table 1$)$ and $\mathrm{C}_{\text {soil }}=$ metal concentration in soil. 


\section{Results and discussions}

\subsection{Concentration of metals in soil}

The results from analysis of variance of the soil data showed non-significant effect $(P>0.05)$ of sites and seasons on concentration of iron in soil (Table 2). Iron concentration in soil samples in at six sampling sites was: Site V > Site VI > Site III > Site II > Site I > Site IV respectively (Table 3).

Table 2. Analysis of variance for iron in soil, forage and blood of buffaloes

\begin{tabular}{|c|c|c|c|c|}
\hline \multirow[t]{2}{*}{ Source of variation } & \multirow{2}{*}{$\begin{array}{l}\text { Degree of } \\
\text { freedom }\end{array}$} & \multicolumn{3}{|c|}{ Mean square } \\
\hline & & Soil & Forage & Blood \\
\hline Sites & 5 & $1.64^{\mathrm{ni}}$ & $0.751^{\mathrm{ns}}$ & $15.93^{\text {nis }}$ \\
\hline Seasons & 1 & $7.84^{\mathrm{ni}}$ & $0.055^{*}$ & $1.261^{\mathrm{ns}}$ \\
\hline Sites Seasons & 5 & $3.411^{\mathrm{ns}}$ & $3.181^{\mathrm{ns}}$ & $0.681^{\text {ns }}$ \\
\hline Error & 36 & $1.393^{\mathrm{ni}}$ & $1.229^{\mathrm{ns}}$ & $1.742^{\mathrm{ni}}$ \\
\hline
\end{tabular}

Table 3. Mean concentration of iron in soil, forage and buffalo blood

\begin{tabular}{|c|c|c|c|}
\hline Sites & Soil & Forage & Buffalo blood \\
\hline Site I & 2.339 & 2.039 & 2.109 \\
\hline Site II & 2.893 & 2.134 & 2.41 \\
\hline Site III & 3.156 & 1.928 & 3.84 \\
\hline Site IV & 2.170 & 2.624 & 3.838 \\
\hline Site V & 3.337 & 1.888 & 5.465 \\
\hline Site VI & 3.280 & 2.184 & 1.737 \\
\hline
\end{tabular}

Nazir and his team [33] and Ravi and Singh [34] studied the heavy metals in forages and the concentration of Fe was found lower as compared to current study. Lesser the traffic on the roads lesser is the iron at the site from where samples were collected. Heavy metals in soil depend on the texture of soil as arid and semi-arid soils contain elevated concentrations of iron unlike the boreal regions and humid tropic zones. Considerably low industrialization and limited anthropogenic activities in the area of study could be responsible for less accumulation of Fe in the agricultural soils [35].

\subsection{Concentration of metals in forages}

Sites affected non-significantly on the concentration of iron whereas, seasons had significant effect on the concentration of iron (Table 2). The concentration of Fe in the samples of forages at the six sites of sampling was: Site IV > Site II > Site VI > site I > Site III > Site V respectively (Table 3). The study done by Cerrilo and his collaborators [36] on the forages reported lower concentration of Fe in the examined samples unlike the concentrations in current study. The concentration of Fe found by Bahadur [37] was the similar to current study. The differences in the concentration of the iron or other heavy metals in the forage depend on the type of forage, extent of soil being contaminated, and physical properties of soil e.g soil $p \mathrm{H}$ etc. Lesser heavy traffic in the one part of the examined area may be responsible for the lower concentration of Fe [38].

\subsection{Concentration of metals in blood}

Analysis of variance of buffalo blood data showed that sites and season had non-significant impact on the concentration of iron (Table 2). Iron concentration in blood samples was of the following order: Site V > Site IV Site > III > Sites II > Site I > Site VI (Table 3). Higher concentration of iron was found in the study coordinated by Malhat et al. [39].

\subsection{Bio-concentration factor for forage and soil}

The order of bio-concentration factor for iron at soil and forage was: Site IV > site II > Site VI > Site III $>$ Site V > Site I respectively (Table 4). The bio-concentration factor obtained by Opulwa [40] was 
higher as compared to current study. BCF of heavy metals depends upon their retention in soil. For instance, lower bio-concentration factor means that the heavy metals do not easily get transported to the forage as they are in tight bonding with the soil. Contrary to that, the higher BCF suggests that the heavy metals are not in tight bonding with the soil and they get readily transferred to the forages [41, 42].

Table 4. Bio concentration factor and correlation of iron in soil-forage and forage-buffalo blood mediums

\begin{tabular}{|c|c|c|}
\hline Sites & Soil-forage & Forage-buffalo blood \\
\hline Site I & 0.26 & 0.79 \\
\hline Site II & 0.73 & 1.16 \\
\hline Site III & 0.610 & 1.98 \\
\hline Site IV & 1.209 & 1.46 \\
\hline Site V & 0.56 & 2.89 \\
\hline Site VI & 0.65 & 0.78 \\
\hline Correlation & -0.434 & -0.218 \\
\hline
\end{tabular}

\subsection{Bio concentration factor for blood and forage}

The order of Bio-concentration factor for blood-forage medium was: Site V > site III > Site IV > Site II $>$ Site I > Site VI respectively (Table 4). According to Liu [32] the BCF if found greater than 1 suggests that the plants can potentially accumulate heavy metals. Alloway and Ayres [43] analyzed that the extent of heavy metal uptake by forages depends upon their age, edaphic factors and the climatic factors. The soil properties like $p \mathrm{H}$ influence the mobility of heavy metals in soil. The movement of the heavy metals was restricted by high value of $p \mathrm{H}$ unlike in case of low $p \mathrm{H}$ [44]. It may be possible that the $p \mathrm{H}$ of examined soil affected the bio-cocnetration factor in current study.

\subsection{Correlation}

The correlation for soil-forage and blood-forage was non-significantly negative (Table 4). The correlation results as reported by Rattan [45] were lower for Fe unlike the analysis done in this study. Negative non-significant correlation was due to more convoluted relationships of heavy metals which mean there is imbalance between the concentrations of iron between soil and forage.

\section{Daily intake of metals}

The daily intake of metal for Fe at six sites of sampling was in the order: Site IV > Site VI > Site II $>$ site V > site III > site I (Table 5). The values of iron concentrations as reported by Lente [46] were found lower contrary to the concentration of iron found in this study. Added by Radwan and Salama [47] that if daily intake of metal does not exceed from 1, it means that there is no health risk associated with the consumption of that diet.

Table 5. DIM, HRI and PLI via consumption of forage from six different sites of Sargodha District

\begin{tabular}{|c|c|c|c|}
\hline Sites & DIM & HRI & PLI \\
\hline Site I & 0.033 & 0.025 & 0.040 \\
\hline Site II & 0.046 & 0.065 & 0.05 \\
\hline Site III & 0.042 & 0.06 & 0.055 \\
\hline Site IV & 0.066 & 0.094 & 0.038 \\
\hline Site V & 0.043 & 0.05 & 0.058 \\
\hline Site VI & 0.063 & 1.09 & 0.057 \\
\hline
\end{tabular}

\subsection{Health risk index}

The health risk index for iron was of the order: Site VI>site IV > site II $>$ Site III $>$ Site V $>$ site I (Table 5). Levels of Fe found by Ashfaq [48] were quite lower unlike the values found in this study. According to Sajjad [49] if the health risk index is found greater than 1 it means that a serious health risk is associated with the consumption of roadside contaminated forages. Health risk index depends on the 
chemical composition and the physical characteristics of soil, type of forage being consumed and rate of consumption of forages.

\subsection{Pollution load index}

Pollution load index for Fe was of the order: Site V > site VI > Site III > site II > site I > site IV (Table 5). Ahmad and his collaborators [50] found lower pollution load index for Fe compared to that found in this study. According to the criteria provided by Thomilson [51] the greater pollution load index by any metal, greater is the pollution in that area and vice versa. For example, values of PLI $<1$ denote perfection, PLI $=1$ presents that only baseline levels of pollutant present PLI > 1 would indicate deterioration of site quality. Pollution load index basically suggests the degree of soil pollution in any area.

\section{Conclusions}

Soil and buffalo blood, Pollution load index value and Bio-concentration factor for blood-forage contained highest Fe in the samples collected from site $\mathrm{V}$ while when the samples collected from site VI were analyzed the highest values of the Fe was found in samples of forages, Health risk Index value was obtained. While the values of Daily intake of metal and bio-concentration factor for forage-soil was found highest in the samples collected from site IV.

Ethics. All the study protocols were approved by Institutional Animal Ethics Committee, University of Sargodha (ApprovalNo.25-A18 IEC UOS). All the experiments performed complied with the rules of National Research Council [55] and all methods were performed in accordance with relevant guidelines and regulations.

\section{References}

1. WARREN, B.P., Heavy metal levels in atmospheric particulates, roadside dust and soil along a major urban highway, Sci. Total Environ., 59, 1987, 233-256.

2. AKOTO, O., EPHRAIM, J.H., DARKO, G., Heavy metal pollution in surface soils in the vicinity of abundant railway servicing workshop in Kumasi, Ghana, Int. J. Environ. Res., 2, 2008, 359-364.

3. MOREKI, J.C., WOODS, T.O., NTHOIWA, P.G., Estimation of the concentration of heavy metals in forages harvested around Dibete area, Botswana, Int. J. Innov. Res. Sci. Eng. Tech., 2, 2013, 30604071.

4. ASLAM, J., KHAN, S.A., KHAN, S.H., Heavy metals contamination in roadside soil near different traffic signals in Dubai, United Arab Emirates, J. Saudi Chem. Soc., 17, 2013, 315-319.

5. STOICA, C., DINU, L., LUCACIU, I., NITA-LAZAR, M., ONCU, V., The Toxic Effect of Conventional Treated Mine Water on Aquatic Organisms, Rev. Chim., 71, 2020, 67-71.

6. EKMEKYAPAR, F., ASLAN, A., BAYHAN, Y. K., CAKICI, A., Biosorption of Pb (II) by nonliving lichen biomass of Cladonia rangiformis Hoffm, Int. J. Environ. Res., 6, 2012, 417-424.

7. DINU, C., UNGUREANU, E.M., VASILE, G.G., KIM, L., IONESCU, I., ENE, C., SIMION, M., Soil and Vegetation Pollution from an Abandoned Mining Area Situated in Hunedoara County, Romania, Rev. Chim., 69, 2018, 14-20.

8. OKUKU, PETER, H.K., Choose of Heavy Metals Pollution Biomonitors: A Critic of the Method that uses Sediments total Metals Concentration as the Benchmark, Int. J. Environ. Res., 6, 2012, 313322.

9. GHADERI, A., ABDULI, A., KARBASSI, M. A., NRABADI, A. R., KHAJEH, T., Evaluating the Effects of Fertilizers on Bioavailable Metallic Pollution of soils, Case study of Sistan farms, Iran, Int. J. Environ. Res., 6, 2012, 565-570.

10. NAWAZISH, S., HUSSAIN, M., ASHRAF, M., ASHRAF, M.Y., JAMIL, A., Effect of automobile related metal pollution $\left(\mathrm{Pb}^{2+}\right.$ and $\left.\mathrm{Cd}^{2+}\right)$ on some physiological attributes of wild plants. Int. J. Agric. Biol., 14, 2012, 953-958 
11. SOFILIC, T., BERTIC, B., SIMUNIC-MENARIC, V., BRNARDIC, I., Soil pollution as a result of temporary steel scrap storage at the melt shop, Ecologia Balkanica, 5, 2013, 21-30.

12. MAFUYAI, G.M., KAMOH, N.M., KANGPE, N.S., AYUBA, S.M., ENEJI, I.S., Heavy metals contamination in road side dust along major traffic roads in Jos metropolitan Area Nigeria. European J. Earth Environ., 2, 2015, 1-14.

13. WASEEM, A., ARSHAD, J., IQBAL, F., SAJJAD, A., MEHMOOD, Z., MURTAZA, G., Pollution status of Pakistan: a retrospective review on heavy metal contamination of water, soil, and vegetables, BioMed Res. Int., 2014, 21-29.

14. GALL, J. E., BOYD, R. S., RAJAKARUNA, N., Transfer of heavy metals through terrestrial food webs: A review, Environ. Monit. Assess. 187, 2015, 201-216.

15. AMINIYAN, M.M., AMINIYAN, F.M., MOUSAVI, R., HEYDARIYAN, A., Heavy metal pollution affected by human activities and different land-use in urban topsoil: A case study in Rafsanjan city, Kerman province, Iran, Eurasian J. Soil Sci., 5, 2016, 97-104.

16. GHOSH, S. P., MAITI, S. K., SINGH, G., Heavy metal contamination in roadside soil and vegetation: A review, Indian J. Environ. Protect., 29, 2009, 334-340.

17. WOO, S.Y., LEE, D.K., LEE, Y.K., Net photosynthetic rate, ascorbate peroxidase and glutathione reductase activities of Erythrina orientalis in polluted and non- polluted areas, Photosynthetica, 45, 2007, 293-295.

18. KHAN, Z.I., SAFDAR, H., AHMAD, K., UGULU, I., WAJID, K., BASHIR, H., DOGAN, Y., Manganese bioaccumulation and translocation of in forages grown in soil irrigated with city effluent: an evaluation on health risk, Res. J. Pharmaceut. Biol. Chem. Sci., 9, 2018, 759-770.

19. KHAN, Z.I., SAFDAR, H., AHMAD, K., WAJID, K., BASHIR, H., UGULU, I., DOGAN, Y., Health risk assessment through determining bioaccumulation of iron in forages grown in soil irrigated with city effluent, Environ. Sci. Pollut. Res., 2019, https://doi.org/10.1007/s11356-019-04721-1.

20. REILLY, C., Metal contamination of food, $2^{\text {nd }}$ ed, Elsevier Applied Science, London, (1991).

21. WOLTERBEEK, B., Biomonitoring of trace element air pollution: principles, possibilities and perspectives, Environ. Pollut., 120, 2002, 11-21.

22. CALZONI, G.L., ANTOGNONI, F., PARI, E., FONTI, P., GNES, A., SPERANZA, A., Active biomonitoring of heavy metal pollution using Rosa rugosa plants, Environ. Pollut., 149, 2007, 239-245. 23. ARINDAM, K., Sagittaria sagittifolia: Bioaccumulator of industrial pollutants. Adv. Plant Sci., 12, 1999, 267-270.

24. DONGARRÀ, G., SABATINO, G., TRISCARI, M., VARRICA, D., The effects of anthropogenic particulate emissions on roadway dust and Nerium oleander leaves in Messina (Sicily, Italy), J. Environ. Monit., 5, 2003, 766-773.

25. KILBURN, M., Aqua Regia Digestion for Soils / Sludges. Analytical methods manual. 2000, Method NO: H115, 03/07/00.

26. JONES, WOLF, MILIS, H.A., Plant Analysis Handbook. Micro-Macro Publishing, Athens, Georgia 30607, USA. 1991, p. 213.

27. RICHARDS, L.A., Diagnosis and Improvement of Saline and Alkaline Soils.1st Ed. Agri. Handbook No. 60. 1968, IBH Pub. Co. New Delhi, India

28. STEEL, R., TORRIE, J.H., Principle and procedures of statistics, a biometrical approach (2nd ED). McGraw Hill Book Co. Inc., New York, 1980, p. 336-354.

29. CHARY, N., KAMALA, C.T., RAJ, D.S. Assessing risk of heavy metals from consuming food grown on sewage irrigated soils and food chain transfer, Ecotoxicol. Environ. Saf., 69, 2008, 513-524.

30. BRIGGS, H., BRIGGS, H.M., Modern breeds of livestock. Fourth edition Mc Million publishing Co, 1980.

31. ***USEPA (US Environmental Protection Agency). Preliminary Remediation Goals, 2002, Region 9. 
32. LIU, W. H., ZHAO, J. Z., OUYANG, Z. Y., SÖDERLUND, L., LIU, G. H., Impacts of sewage irrigation on heavy metal distribution and contamination in Beijing, China, Environ. Int., 31, 2005, 805812.

33. NAZIR, R., KHAN, M., MASAB, M., REHMAN, H., RAUFI, N., SAHABI, S., AMEERI, N., SAJEDI, M., ULLAH, M., SHAHEEN, Z., Accumulation of Heavy Metals (Ni, Cu, Cd, Cr, Pb, Zn, Fe) in the soil, water and plants and analysis of physico-chemical parameters of soil and water Collected from Tanda Dam kohat), J. Pharmaceut. Sci. Res., 7, 2015, 89-97.

34. RAVI, K., SINGH, S., Levels, Spatial Distribution and Possible Sources of Heavy Metal Contamination of Suburban Soil in Jhansi, Orient. J. Chem., 28, 2012, 1913-1918.

35. AKSOY, A., OZTURK, M.A., Nerium oleander L. as a Biomonitor of Lead and Other Heavy Metal Pollution in Mediterranean Environments, Sci. Total Envirn., 205, 1997, 145-150.

36. CERILLO-SOTO, M.A., NEVAREZ-CARRASCO, G., RAMIREZ-LOZANO, R.G., NUNEZGONZALES, A., GARCIA-DIAZ, G., JUAREZ-REYES, A.S., Mineral profile of diets consumed by range Spanish goats in a shrubland of North Mexico, South African J. of Animal Sci., 34, 2004, 117-119. 37. BAHADUR, A., CHAUDHRY, Z., JAN, G., DANISH, M. et al. Nutritional and elemental analyses of some selected fodder species used in traditional medicine, African J. Pharm. Pharmacol., 5, 2011, 1157-1161.

38. HUSTON, J.E., WHITE, R.G., BEQUETTE, B.J., DOVE, H., GOETSCH, A.L. et al., Nutrient Requirements of Small Ruminants: Sheep, Goats, Cervids, and New World Camelids. The National Academies Press. 2006, Washington, D.C.

39. MALHAT, F., HAGAG, M., SABER, A. FAYZ, A.E., Contamination of Cows Milk by Heavy Metal in Egypt, Bull. Environ. Contam. Toxicol., 88, 2012, 611-613. https://doi.org/10.1007/s00128012-0550-X.

40. OPULWA, O.D, AREMU, M.O., OGBO, L.O., ABIOLA, K.A., ODIBA, I.E., ANUBAKAR, M.M., NWEZE, N.O., Heavy metal concentrations in soils, plants leaves and crops grown around dump sites in Lafia Metropolis, Nasarawa State, Nigeria, Adv. Appl. Sci. Res., 3, 2012, 780-784.

41. ZHANG, H., LUO, Y., SONG, J., ZHANG, H., XIA, J., ZHAO, Q., Predicting As, Cd and Pb uptake by rice and vegetables using field d36ata from China, J. Environ. Sci., 23, 2011, 70-78.

42. CUI, Y.L., ZHU, R.H., ZHI, R.H., CHEN, D.Y., HUANG, Y.Z., QIU, Y., Transfer of metals from soils to vegetables in an area near a smelter in Nanning, China, Environ. Int., 30, 2004, 785-791.

43. ALlOWAY, B.J., AYRES, D.C., Chemical Principles for Environmental Pollution. Blackie Academic Profes., 1997, p.190-220.

44. CELECHOVSKA, O., MALOTA, L., ZIMA, Z., Entry of heavy metals into food chains: a 20-years comparison study in the Northern Moravia (Czech republic), Acta Veterinaria Brno, 77, 2008, 645-652. 45. RATTAN, R.K., DATTA, S.P., CHHONKAR, P.K., SURIBABU, K., SINGH, A.K., Long-term impact of irrigation with sewage effluents on heavy metal content in soils, crops and groundwater-a case study, Agric. Ecosys. Environ., 109, 2005, 310-322.

46. LENTE, I., OFOSU-ANIM, J., BRIMAH, A.K., ATIEMO, S., Heavy metal pollution of vegetable crops irrigated with wastewater 41 heavy metal pollution of vegetable crops irrigated with wastewater in Accra, Ghana, West African J. Appl. Ecol., 22, 2014, 41-58.

47. RADWAN, M.A., SALAMA, A.K., Market basket survey for some heavy metals in Egyptian fruits and vegetables, Food Chem. Toxicol., 44, 2006, 1273-1278.

48. ASHFAQ, A., KHAN, Z.I., BIBI, Z., AHMAD, K., ASHRAF, M., MUSTAFA, I., AKRAM, N.A., PERVEEN, R., YASMEEN, S., Heavy metals uptake by Cucurbita maxima grown in soil contaminated with sewage water and its human health implications in peri-urban areas of Sargodha city, Pak. J. Zool., 47, 2015, 1051-1058.

49. SAJJAD, K., FAROOQ, R., SHAHBAZ, S., KHAN, M.A., SADIQUE, M., Health risk assessment of heavy metals for population via consumption of vegetables, World Appl. Sci. J., 6, 2009, 1602-1606. 
50. AHMAD, K., KHAN, Z.I., ASHFAQ, A., ASHRAF, M., YASMIN, S., Assessment of heavy metal and metalloid levels in spinach (Spinacia oleraceaL.) grown in wastewater irrigated agricultural soil of Sargodha, Pakistan, Pak. J. Bot., 46, 2014, 1805-1810.

51. TOMLINSON, D.L., WILSON, J.G., HARRIS, C.R., JEFFREY, D.W., Problems in the assessment of heavy-metal levels in estuaries and the formation of a pollution index, Helgoländer meeresuntersuchungen, 33, 1980, 566.

52. SINGH, A., SHARMA, R.K., AGARWAL, M., MARSHAL, F.M., Health risk assessment of heavy metals via dietary inake of foodstuffs from wastewater irrigated site of dry tropical area of India, Food Chem. Toxicol., 48, 2010, 611-1619.

53. DOSUMU, O.O., ABDUS-SAlAM, N., OGUNTOYE, S., AFDEKALE, F.A., Trace metals bioaccumulation by some Nigerian vegetables, Centrepoint, 13, 2005, 23-32.

54. ***Dutch standards. Circular on target values and intervention values for soil remediation. 2000.

55. ***National Research Council. Guide for the care and use of laboratory animals. Washington, D.C., 1996, National Academy Press.

Manuscript received: 6.05.2020 